\title{
IDENTIFICATION OF HUNTETE BEACH TOURISM OBJECT IN KULATI VILLAGE EAST TOMIA SUB- DISTRICT WAKATOBI REGENCY
}

\author{
La Ode Amaluddin ${ }^{1}$, Andri Estining Sejati ${ }^{2}$, Fahrudi Ahwan Ikhsan ${ }^{3}$, Mutiana ${ }^{1}$ \\ ${ }^{1}$ Department of Geography Education, Halu Oleo University \\ ${ }^{2}$ Department of Geography Education, Sembilanbelas November Kolaka University \\ ${ }^{3}$ Department of Geography Education, University of Jember \\ Email: amaluddin75@gmail.com
}

Received:1 October 2018/Revised:7 November 2018/Accepted: 5 December 2018/Published online:31 December 2018

\begin{abstract}
Huntete Beach has good physical potention, but still not optimal visitors. The purposes of this paper there are two (a) to determine the potention of Huntete Beach tourism objects in Kulati Village, East Tomia Subdistrict, Wakatobi Regency with spatial analysis views, (b) To find out the perception of tourists on the potential of Huntete Beach tourism objects in Kulati Village, East Tomia District, Wakatobi Regency. This research uses survey method. The results of this paper are (a) the potential of Huntete Beach is in the medium category (internal potential) and low (external potential), so it needs to be developed again so that it can become a main tourism object in East Tomia Subdistrict, Wakatobi Regency, (b) Presumption from tourists who visit that there is a potential in Huntete Beach tourism, so needs better management by completing facilities that are not yet available. It can tourists more enjoy the natural phanorama and not feel bored at this place.
\end{abstract}

Keywords: potential identification, tourism object, Huntete beach

\section{Introduction}

Wakatobi Regency South East Sulawesi is an area that is actively developing its regional potential for tourism resort. Tourist resorts in Wakatobi pull tourists interest to visit. Tourism in Wakatobi has been established by the Ministry of Culture and Tourism of the Republic of Indonesia as a national maritime tourism development area. The Ministry of Forestry has also designated Wakatobi Islands as a conservation area with National Park status. This shows that Wakatobi is a natural tourism area. According to (Sutedjo and Murtini, 2007) Natural tourism objects, namely the form or form of this object in the form of scenery such as the form of mountainous, coastal or aquatic, the environment in the form of life, flora and fauna. According to (Law Number 9 year 1990) tourism is a travel activity or part of the activity is carried out voluntarily and temporarly, to enjoy tourism objects and attractions. According to (Pearce in Sujali, 1989) tourism as a symptom relationship that arises from the journey and the stay of someone or a group of people due to recreational purposes.

Tourist visits are currently focused on the Wakatobi National Park. There are many other natural objects in Wakatobi Regency that can be developed for tourism activities. Tourism activities is the kind activties atractions in the tourism resort, there are: natural, culture, human made, special interest. One of tourism activities focus at natural is Huntete Beach tourist attraction. According to (Damanik, 2006) one of the objects on which tourism is based is nature and blue (clear and clean sea). This natural attraction has the highest value in tourist satisfaction for tourists. 
The beach is a tourist attraction that many people visit in filling their holidays. After the climate, coast and sea are the most important geographic aspect in tourism. Beach is an important asset in tourism. According to (Nugroho in Devina, 2011), beach tourism is a beach that has attraction as a tourist spot both physical factors, attractions, facilities, and others. According to (Burton, 1995) as a natural tourism, the beach must have a beautiful physical form, such as clean, sandy and comfortable to sunbathand safeable to swim with calm waves which can also makes children play on the beach.

Huntete Beach is located in Kulati Village in the administrative area of East Tomia Sub-district. This tourism object has the longest beach characteristics on Tomia Island. Huntete Beach can be reached by 2-wheeled vehicles, 4-wheeled vehicles and marine vehicles towards the west of Kulati Village with a distance of $2 \mathrm{~km}$ to the south of Kulati. White sand expanse on Huntete beach with the Banda'sseawaves and many fish passing through the coastal waters when the tide arrives makes this beach a beautiful place, turtles also come at night to lay eggs in this place. According to (Freuler in Pendit, 2003) tourism in the modern sense is a phenomenon from the present era based on the need for health and the changing of air for breathe, built a sense of natural beauty, to get pleasure. According to (Pearce, 1983) the locational factors that influence the development of tourism potential are physical condition, accessibility, ownership and land use, barriers and support and other factors such as labor wages and political stability.

Other activities that can be done are diving, snorkeling, and sunbathing. Some diving points are included in the best category in Tomia. The challenge in this Huntete Beach tourist attraction is not visited yet by many both Indonesian and International tourists. According to (Suwantoro, 2004) in addition to the basic elements that must be considered in tourism include tourist objects and attractions, tourism infrastructure, tourism facilities, infrastructure and community/environment. According to (Yoeti, 1997) tourist attraction is everything that is found in tourist destinations which is an attraction so that people want to come and visit a tourist destination.

Based on this, an effort is needed to identify the potential of Huntele beach tourism objects. Research can describe the ability of regions in terms of resources and planning and management capabilities. According to (Damardjati, 1995) tourism potential encompasses all things in real and non-palpable conditions that are worked on, regulated, and provided in such a way that they can be useful or utilized, manifested as the ability of factors and elements needed or determine tourism development, whether in the form of atmosphere, events, objects or services or merit.

There are two research aims. First, to determine the potential of Huntete Beach tourism objects is determined by looking at several variables including internal factors, the quality of objects, condition of objects and support for object development. External factors are accessibility, complementary facilities and object support facilities. All potential use spatial analysis views. Second, the characteristics of tourists can be seen including the origin of tourists, age, and final education, while the perception of tourists can be seen from the tourist responses to Huntete Beach tourist attractions. According to (Suwantoro, 1997) generally the attraction of a tourist object is based on: (1) resources that can cause pleasure, beauty, comfort, and clean. (2) high accessibility to be able visit it. (3) There are special/specific characteristics that are rare. (4) The existence of supporting facilities/infrastructure to serve the tourists present. (5) Natural tourism objects have high attraction because they have special values in the form of art attractions, traditional ceremonies, noble values contained in an object of human work in the past.

\section{Method}

This research used survey method. Survey can descibe phenomena form many population. This research was carried out in June 2017. This research place was in Kulati Village, East Tomia 
tourist. Huntete Beach tourism objects both internal and external factors. The sampling of visitors (tourists) in this study was determined by quota sampling there are 40 respondents. The sampling technique was carried out using the accidental sampling method, which is how to obtain samples based on who happened to be encountered while conducting the research. According to (Singarimbun, Masri and Effendi, 2008), survey concluded big population from sampel. According to (Sugiyono, 2008) the population is an area of generalization consisting of objects or subjects that have product quality and certain characteristics set by researchers to be studied and then drawn conclusions.

The data in this research is a combination of primary data and secondary data. Analysis of data in the study using scoring techniques seen from the interval class. Data were also analyzed qualitativewith the percentage of choices submitted by respondents determined by the formulation of Muktar, Erna and Widodo (2000). Interval class using that formula.

$$
\begin{aligned}
& K=\frac{a-b}{y} \\
& K=\text { Interval class } \\
& a=\text { High potential value } \\
& b=\text { Low potential value } \\
& y=\text { Total class }
\end{aligned}
$$

Class use likert scale, the total is five. Each criteria scoring from interval class range. Then The total divided become five classifivcation, there are: very low, low, moderate, high, and very high.

\section{Result and Discussion}

\begin{tabular}{|c|c|c|c|}
\hline Internal Factor & $\begin{array}{c}\text { Delails } \\
\text { Potention }\end{array}$ & Criteria & Score \\
\hline \multirow[t]{6}{*}{ Object quality } & A. & $\begin{array}{l}\text { The beach that presents the beauty of natural scenery in the } \\
\text { form of white sand and coral reefs }\end{array}$ & 2 \\
\hline & B. & $\begin{array}{l}\text { The combination of components is less able to enhance the } \\
\text { quality of objects }\end{array}$ & 2 \\
\hline & C. & Objects do not have supporting attractions yet & 1 \\
\hline & D. & Tourist catch atraction & 2 \\
\hline & E. & $\begin{array}{l}\text { There is no trash and the water in the toilet that is not } \\
\text { available yet makes the environment look less clean. }\end{array}$ & 2 \\
\hline & $\mathrm{F}$. & The object has not been properly treated & 2 \\
\hline \multirow{5}{*}{$\begin{array}{l}\text { Tourism object } \\
\text { contitions }\end{array}$} & G. & Clear and clean sea water & 2 \\
\hline & H. & 2 to 3 activities & 2 \\
\hline & I. & Quite interesting Object & 2 \\
\hline & J. & Quite confort Object & 2 \\
\hline & $\mathrm{K}$. & Safety in objects is quite guaranteed & 2 \\
\hline \multirow{5}{*}{$\begin{array}{l}\text { Supports object } \\
\text { development }\end{array}$} & L. & Parallel objects have tourism objects support & 2 \\
\hline & M. & The available land area for development is still sufficient & 2 \\
\hline & N. & $\begin{array}{l}\text { It will only be planned by the local government tour } \\
\text { package }\end{array}$ & 2 \\
\hline & & Total score & 26 \\
\hline & & Clasification & rate \\
\hline
\end{tabular}

Identification of Huntete Beach tourism potential consists of internal and external potential. The internal potential of Huntete Beach tourism objects can be seen in the following table:

Table1 Internal Potentions of Huntete Beach Tourism Object 
Source: Research result, 2017

Based on the results of the data analysis above obtained internal potential assessments indicate that Huntete Beach tourism objects are potentially moderate with a score of 26 . These results can be projected that the internal potential possessed by Huntete Beach attractions has a strong natural element such as the scenery with cool air, the beauty of sand white, unique coral reefs, and has historic caves. Natural conditions and types of vegetation in Huntete Beach are natural scenery that can provide comfort for tourists.

The internal potential of Huntete Beach tourism objects can be seen in the following table:

Table2.External Potentions of Huntete Beach Tourism Object

\begin{tabular}{|c|c|c|c|}
\hline External Factor & $\begin{array}{c}\text { Delails } \\
\text { Potention }\end{array}$ & Criteria & Score \\
\hline \multirow[t]{2}{*}{ Accesibility } & A. & Available, but conditions are quite good & 2 \\
\hline & B. & Not available & 1 \\
\hline \multirow{2}{*}{$\begin{array}{l}\text { Object Support } \\
\text { Facilities }\end{array}$} & C. & 45 minute & 2 \\
\hline & D. & Not awailable & 1 \\
\hline \multirow{2}{*}{$\begin{array}{l}\text { Complement } \\
\text { Facilities }\end{array}$} & E. & Available building to enjoy the object & 2 \\
\hline & F. & $\begin{array}{l}\text { Available parking area, toilet or Tersedia lahan } \\
\text { parkir, toilet/bathroom }\end{array}$ & 2 \\
\hline & & Total score & 10 \\
\hline & & Classification & Low \\
\hline
\end{tabular}

Source: Research result, 2017

Based on the analysis above, it is known that the scores of Huntete Beach tourism objects included in the classification of low potential, in this case need to be developed better. Complementing facilities and infrastructure for tourist needs that are not yet available in Huntete Beach tourism objects are expected to attract tourists who visit and feel comfortable. This internal external state is in line with the SWOT method, where the SW is internal and external OT. According to (Rangkuti, 2004), SWOT analysis is a situation analysis conducted by identifying various factors systematically to formulate a strategy. According to (Maramin, 2004), the step after SWOT calculation is to compile an internal matrix/IFAS (Internal Strategic Factors Analysis Summary) as well as external/EFAS (External Strategic Factors Analysis Summary) to identify the position of ecotourism objects and develop development strategies. Huntete Beach based on data shows that internal conditions are good but have great opportunities to be developed into natural attractions.

The identification of Huntete Beach tourism potential in line with spatial analysis. The coastal line spetially for identificataion sea water conditon use buffer line amount of 50 meters from coastal line to sea. The basic map use image from SAS Planet. Acoording to (Prahasta, 2002), anatomically buffer is outsite direction zone from a map object such point, polyline, and polygon.

Characteristics of tourists who come to Huntete Beach attractions can be described, first, group of tourists according to gender. Based on gender, most tourists visiting Huntete Beach are male $60 \%$ while female is $40 \%$, the difference in number based on sex is not very influentialbecause Huntete Beach is a tourist attraction that is open for activities travel. According to questionnaire data and finding data in the field, visitors at these tourist sites mostly come in groups or families where the male ratio is greater. According to (The International Ecotourism Society-TIES in Damanik and Weber, 2006) environment-based tourism is no longer the dominance of men, care and needs in the natural environment are also important characteristics of female tourists. 
The second, level of education, the biggesttourists education are $45 \%$ undergraduate, $35 \%$ senior high schooland the smallest frequency is tourists with elementary school education 20\%. Motivation of tourists visiting Huntete Beach tourism is mostly for the purpose of free time, looking for fresh air and making observations to expand knowledge. According to (Pitmann et al, 2010), many people with adult learning do tourism activities.

Third, origin of tourists. Tourists who visit Huntete Beach attractions are mostly domiciled in Tomia and Outside Wakatobi, generally from various cities in Indonesia and abroad. The highest number of tourists comes from Tomia, Wakatobi (30\%). This is because Huntete Beach tourism objects are not too widely known. The presence of tourists both at home and abroad makes this tourism object a great potential for other tourists to visit. This is because tourists tend to influence other tourists to visit a tourist attraction. According to (Yang and Lo, 2018) tourist arrivals in a place affect the increase in the number of tourists coming from other regions, in this case Chinese tourists affect Taiwanese tourists.

The Fourth, the distance perception of residence to tourist attractions. $50 \%$ of travelers agree to have a distance of more than $>10 \mathrm{~km}, 25$ very agree, $20 \%$ disagree and $5 \%$ strongly disagree. The five dominant transportation tools used by tourists are $65 \%$ of cars. The six tourist ratings on Huntete Beach attractions are in good condition 50\% and very good 50\%. This allows Huntete Beach to be developed better as a tourist attraction. According to (Lohmann and Pearce, 2012) transportation with modes of transportation affects the development of tourist attractions, for example connecting Wellington and Picton in New Zealand with a ferry.

Seventh, the reason tourists are interested in visiting Huntete Beach attractions is one of the reasons for having a unique natural panorama. Tourists will choose a place that has interesting and unique natural scenery, so that when visiting tourists are amazed by the beauty of the panorama that the object has. Travelers judge the location is very convenient for travel. Eighth, 60\% agreed that the attraction was interesting. This is seen in its natural beaches, clear sea water and clean white sand. According to (Arida et al, 2017) one of the development of tourism is based on natural potential such as Mambal village which has extensive natural rice fields, a natural Senaung Pengibull's cave which is formed naturally, and pancoran pitu.

Nineth, $25 \%$ of respondents said that tourism was less safe due to the absence of intensive supervision carried out at Huntete Beach tourist sites. This is necessary for supervision to be carried out so that tourists who visit feel safe and comfortable in traveling.

Tenth, the availability of facilities and infrastructure at Huntete Beach tourism objects is not yet well approved $25 \%$ respondem. This requires the attention of the government and the local community to provide inadequate deficiencies in tourist attractions in order to attract more tourists. Eleventh, most tourists argue that the facilities that need to be addressed are the water facilities that are jammed, roads that are not good, parking lots that are not yet well available, cleanliness in the environment of the object being guarded, and the need for special supervision in tourist attractions. In this case, the need to pay attention to the shortcomings in Huntete Beach tourism objects so that tourists are more comfortable and attractive to visit again. According to (Hanifah et al, 2018), tourism objects that are close to health facilities are complementary. According to (Lumbanraja, 2012) one of development tourism area is availability of facilities.

Twelfth, tourists are very supportive if Huntete Beach tourism objects are developed so that they are more famous in accordance with their potential. Judging from the increasing flow of visits, tourists on Huntete Beach have prospects for development. Where there is a motivation for tourists to do tourism activities, it is expected that it will also bring a better influence on the surrounding community. Thirteen, tourists agree that Huntete Beach tourism objects are developed for arts and cultural activities and campground activities. Each of them is $45 \%$ and $30 \%$. This aims to preserve and introduce various arts and cultures in Wakatobi. According to (Culusjarvi, 2016) the development of tourist attractions is a combination of 
natural environment and human activities, such as in Northern Finland that requires regional studies.

\section{Conclusion}

There are two conclusions that can be taken from this research: First, the potential of Huntete Beach is in the medium category, seen from internal potential. While the external potential is included in the low category so it needs to be developed again so that it can become a maintourism object in East Tomia Sub-district, Wakatobi Regency. Second, there is an assumption for tourists who visit that there is a potential in Huntete Beach tourism object so that it needs better management by completing facilities that are not yet available so that tourists who come to visit can enjoy the natural beauty and not feel bored at the place.

\section{References}

Arida, I, N, S., Wiguna, P, P, K., Narka, I, W., dan Pebrianti N, K, O. 2017. Development planning of tourist village using participatory mapping (Case study: Mambal Village, Badung Regency, Indonesia). IOP Conf. Series: Earth and Environmental Science 98 012044: 1-10.

Burton, Rosemary.1995.TravelGeography. London: Pitman Publishing.

Culusjarvi, Outi. 2016. Resort-oriented tourism development and local tourism networks-a case study from Northern Finlan.VENNIA 194 (1): 3-17

Damanik J dan Weber H.F. 2006. Perencanaan Ekowisata dari Teori ke Aplikasi. Yogyakarta: PUSPAR UGM \& Penerbit Andi.

Damardjati, R.S. 1995. Istilah-istilah Dunia Pariwisata. Jakarta: Gramedia Pustaka Umum.

Devina, 2011. Tingkat Daya Tarik Objek Wisata Pantai di Wilayah Karst Kabupaten Gunung Kidul. Depok: Universitas Indonesia.

Hanifah dkk. 2018. Analysis of tourist travel patterns toward health care facilities (Case study of Prambanan Sub-District, Klaten District. Geosfera Indonesia 3 (2): 1-10.

Law No. 9 Year 1990 about Tourism.

Lumbanraja, Victor. 2012. Tourism area life cycle in lake toba. Indonesian Journal of Geography 44 (2): 150-160.

Lohmann, Gui, dan Pearce, D, G. 2012. Tourism and transport relationships: the suppliers' perspective in gateway destinations in New Zealand. Asia Pacific Journal of Tourism Research 17(1): 14-29.

Maramin. 2004. Teknik dan Aplikasi Pengambilan Keputusan Kriteria Majemuk. Jakarta: Gramedia Widiasarana Indonesia.

Pearce, Douglas. 1983. Toursit Development Topics In Applied Geography. England: Longmand Group Limited.

Pendit, Nyoman, S. 2003. Manajemen Kepariwisataan. Jakarta: Pradnya Paramitha.

Pitmann, T., Broomhall, S., McEwan, J., dan Majocha, E. 2010. Adult learning in educational tourism. Australian Journal of Adult Learning 50 (2): 219-238.

Prahasta, Eddy. 2002. Konsep-konsep Dasar Sistem Informasi Geografis. Bandung: Informatika.

Rangkuti, F. 2004. Riset Pemasaran (Edisi 2). Yogyakarta: Andi Offset.

Singarimbun, Masri dan Sofian Effendi. 2008. Metode Penelitian Survei. Jakarta: LP3ES.

Sugiyono, 2008. Metode Penelitian Bisnis. Bandung: Alfabeta.

Sujali, 1989. Geografi Pariwisata dan Kepariwisataan. Fakultas Geografi UGM: Yogyakarta.

Sutedjo, Agus dan Murtini Sri. 2007. Geografi Pariwisata. Surabaya: Penerbit Unesa University Press

Suwantoro, Gamal, 1997. Dasar-dasar Pariwisata.Yogyakarta: Andi.

Suwantoro, Gamal. 2004. Dasar-dasar Pariwisata. Yogyakarta: Andi. 
Widodo, Erna Dan Mukhtar. 2000. Konstruksi Kearah Penelitian Deskriptif. Yogyakarta: Avirouz.

Yang, Chih-Hai dan Lo, Pei-Ling. 2018. How the influx of Chinese tourists affects national tourism behaviors: Evidence from Taiwan. International Journal of Tourism Research 20 (5): 543-553.

Yoeti.Oka A. 1997. Perencanaan dan Pengembangan Pariwisata. Jakarta: PT Pradnya Paramita. 